\title{
A COMPARATIVE STUDY OF THE THERMAL DEPENDENCE OF CONTRACTILITY IN SAURIAN SKELETAL MUSCLE*
}

\author{
PAUL LICHT $\dagger$ \\ Department of Zoology, The University of Michigan, Ann Arbor
}

(Received 13 April 1964)

\begin{abstract}
The effects of temperature on tension development in vitro were examined in the pubioischiotibialis muscle from five species of lizards.

2. Pronounced interspecific differences were evident in the optimal temperatures for isometric twitch tension and in the resistance to irreversible heat damage and heat rigor in the muscle.

3. A good correlation is evident between the thermal relations of the muscle and the extent of thermophily of the intact animal as judged by its preferred temperature and heat tolerance. Thus, adjustments at the tissue level appear to play a role in the thermal adaptations of lizards.
\end{abstract}

\section{INTRODUC'TION}

This study represents part of a continuing effort to elucidate the mechanisms involved in the thermal adaptations of lizards. Pronounced interspecific differences were evident in the thermal optima and thermostabilities of the enzyme myosin ATP-ase from lizards having diverse temperature preferences (Licht, 1964a). The importance of this enzyme in muscular contraction suggested that adjustments in the temperature dependence of the skeletal muscles might also be present in these animals.

The thermal relations of saurian skeletal muscle have been characterized largely in terms of thermostability or heat resistance. For example, differences in the temperatures producing heat contractures (Patzl, 1933) and loss of excitability (Ushakov, 1959) have been demonstrated in the skeletal muscles from a variety of lizards. In at least one case these differences appeared related to the overall heat tolerance of the species (Ushakov \& Darevskii, 1960). However, adjustments in heat resistance are not necessarily associated with adjustments of capacities in normal physiological ranges of temperature (Precht, 1958). Consequently, the present investigation was undertaken to examine the effects of temperature on muscular contractility in relation to the body temperatures at which the lizards are normally active (the preferred temperatures). For this purpose measurements

* Work supported in part by Grant G-9238 from the National Science Foundation to Dr. W. R. Dawson and NSF cooperative fellowship for the year 1962-63 to the author.

$\dagger$ Present address: Department of Zoology, University of California, Berkeley. 
were made of the influence of temperature on the tension development in isometric twitches by the pubioischiotibialis muscle-one of the prominent components of the hind limb musculature.

\section{Experimental animals}

\section{MATERIALS AND METHODS}

Muscles were obtained from representatives of five species: Dipsosaurus $d$. dorsalis, Uma $n$. notata, Sceloporus undulatus fasciatus, Eumeces obsoletus and Gerrhonotus $m$. multicarinatus (listed in order of decreasing thermophily). The average body weights were $30,18,6,15$ and $15 \mathrm{~g}$, respectively. The representatives of each species were collected from the same populations as those used in the study of myosin ATP-ase (Licht, 1964a).

All studies were performed from June through August, using individuals that had been in captivity less than 1 week. Prior to study, the lizards were kept in cages fitted with incandescent lamps providing light and heat for $12 \mathrm{hr}$ daily; they were allowed to cool to room temperature at night.

\section{Preparation of muscles}

Lizards were narcotized by chilling and then pithed. The skin was stripped from one of the hind limbs to expose the pubioischiotibialis muscle on the inner face of the thigh. A thread (No. 50 cotton, mercerized) was tied around the tendon at the knee insertion and the muscle was removed with a portion of the pelvic bone on which it originates. After dissection, the muscle was equilibrated for $15 \mathrm{~min}$ at $20^{\circ} \mathrm{C}$ in Ringer's solution $\left(155 \mathrm{mM} \mathrm{NaCl}, 4 \mathrm{mM} \mathrm{KCl}, 2 \mathrm{mM} \mathrm{CaCl} \mathrm{md}_{2}\right.$ and

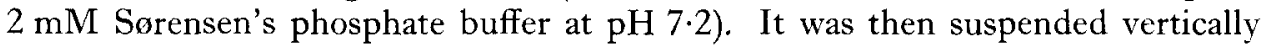
between two platinum ring electrodes which were mounted on the side of a glass aerating tube. One end of the muscle was attached via a thread to a platinum hook on the bottom of the aerating tube and the thread attached to the tendon of the muscle was tied to the lever of a mechano-electrical transducer tube (RCA 5734) mounted above the electrodes. The apparatus was positioned to remove slack from the supporting threads. Preliminary tests showed that the slight tension of the muscle thus produced increased the absolute tension development during the twitch but did not significantly alter the nature of the response to temperature. The electrodes and muscle were immersed in a test-tube containing Ringer's solution. This tube could be replaced by one containing a solution of a different temperature without disturbing the position of the muscle. Humidified oxygen was continually bubbled through the solution bathing the muscle.

Contractions were produced with rectangular wave pulses delivered by a Grass Model S-4 stimulator, and impulses from the transducer tube were recorded on a Sanborn direct writing oscillograph equipped with a d.c. preamplifier. Since the maximal vertical deflection of the transducer tube lever against which the muscle pulled was less than half a degree of arc, the contractions of the muscle were virtually isometric. The voltage and duration of the electrical stimuli were kept well above threshold levels to insure the greatest possible tension development at each temperature. 

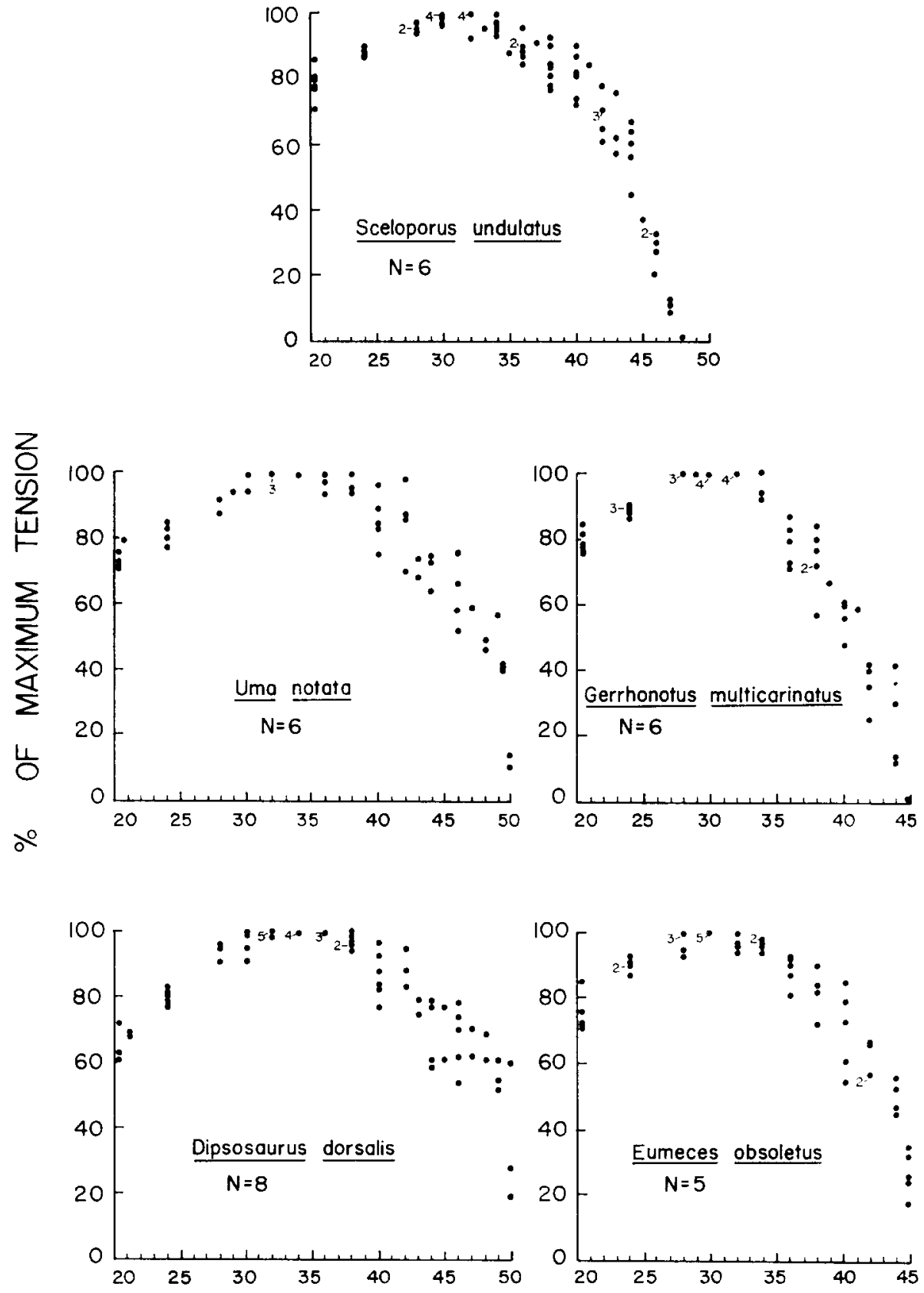

\section{TEMPERATURE $\quad{ }^{\circ} \mathrm{C}$}

FIG. 1. The influence of temperature on the contractility of skeletal muscle (pubioischiotibialis) from five species of lizards. $\mathrm{N}=$ number of individuals studied. Small numerals indicate the appropriate values of points representing two or more observations. 


\section{Effects of temperature on contractility}

Tension development by each muscle preparation was measured at intervals of $2-4^{\circ} \mathrm{C}$ between $18^{\circ}$ and $50^{\circ} \mathrm{C}$ starting with the lowest temperature. The muscle was allowed to adjust to each temperature for $5 \mathrm{~min}$ before stimulation. Before and after exposure to each experimental temperature, control measurements were made at $24^{\circ} \mathrm{C}$ (reference tension) to compensate for any effects from factors such as fatigue or heat injury. The tension developed at each experimental temperature was expressed as a percentage of the preceding reference tension. 'These relative tension values were subsequently converted to a percentage of the maximal tension developed by the preparation in the course of the experiment, i.e. the highest tension relative to the preceding reference value was taken as 100 per cent.

\section{RESULTS}

\section{Optimal temperatures for tension development}

The relative tensions developed during twitches in electrically stimulated muscles from the five species studied are plotted against temperature in Fig. 1. In all preparations tension increased up to a maximal level at some intermediate temperature, designated as the optimum, and then remained constant for several degrees $-7^{\circ}$ in Dipsosaums and $4^{\circ}$ in the others. 'The tension then decreased

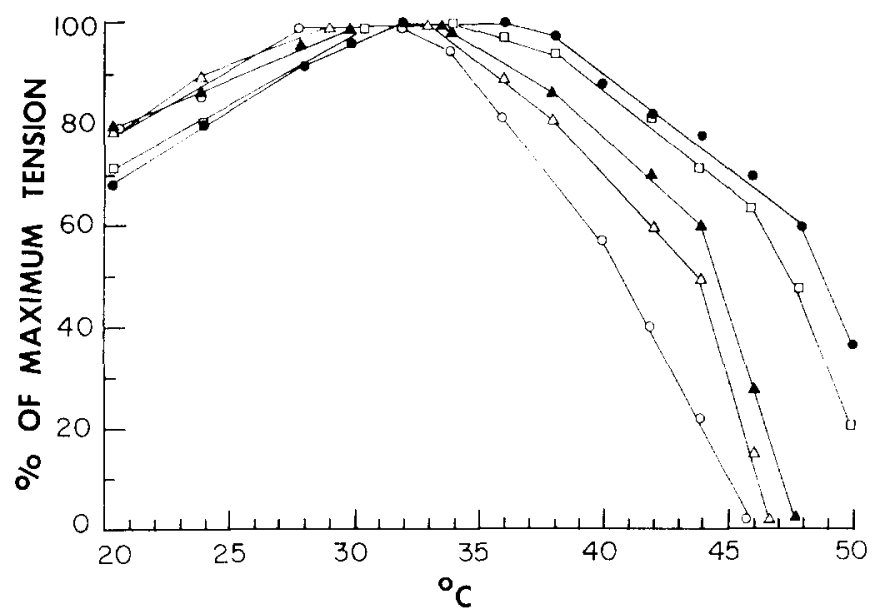

FIG. 2. Comparison of the temperature dependence of muscular contractility in lizards. Points represent average values for 2 intervals from Fig. 1: - $D$. dorsalis; $\square, U$. notata; $\mathbf{\Delta}$, S. undulatus;, E. obsoletus; G, G. multicarinatus.

gradually for about $10^{\circ} \mathrm{C}$, beyond which it began to fall precipitously. Muscle excitability was completely lost within $1-3^{\circ}$ above the point where this precipitous decline commenced. The muscles from Gerrhonotus differed slightly in lacking the sharp decline in tension in the last few degrees.

Although the muscles from all five species show the same general pattern of thermal response, pronounced differences are evident in the positions of the 
tension-temperature curves (Fig. 2). In general, those muscles having the highest optimal temperatures develop a significantly greater proportion of their maximal tension above $42^{\circ} \mathrm{C}$, but differences are less pronounced at sub-optimal temperatures.

\section{Thermostability of muscles}

The thermostability of each muscle preparation was estimated from the extent of irreversible damage at various temperatures and by the temperature at which excitability was completely lost.

The muscle was judged to be irreversibly damaged at a given temperature when the tension, subsequently developed at $24^{\circ} \mathrm{C}$, was reduced from that developed prior to the exposure to that temperature. Such declines in reference tension were usually very small or absent until the muscle had been exposed to temperatures approaching the level at which the relative tension was only about half of the maximum. After such exposures a marked reduction ( $>20$ per cent) in the subsequent reference tension frequently occurred. The average temperatures producing these marked declines are given in Table 1.

Table 1 - Comparison of THE THERMal relations of SKeletal Muscles and of INTACT LIZARDS

\begin{tabular}{|c|c|c|c|c|c|}
\hline \multirow[b]{2}{*}{ Species } & \multicolumn{2}{|c|}{ Body temp. relations* } & \multicolumn{3}{|c|}{ Temp. dependence of muscle } \\
\hline & $\begin{array}{l}\text { MBT } \\
(\mathrm{C})\end{array}$ & $\begin{array}{l}\text { CTM } \\
(\mathrm{C})\end{array}$ & $\begin{array}{c}\text { Maximal } \\
\text { tension } \\
\left({ }^{c} \mathrm{C}\right)\end{array}$ & $\begin{array}{c}\text { Damaging } \\
\text { temp. }{ }^{\dagger} \\
\left({ }^{\circ} \mathrm{C}\right)\end{array}$ & $\begin{array}{c}\text { Lethal } \\
\text { temp. } \\
\text { ('C) }\end{array}$ \\
\hline D. dorsalis & $38 \cdot 8$ & $48 \ddagger$ & $31-38$ & $47 \cdot 5$ & 51 \\
\hline$U$. notata & $37 \cdot 5$ & $>45 t$ & $32-36$ & 47 & $50 \cdot 5$ \\
\hline S. undulatus & $36 \cdot 3$ & $43 \cdot 7 \S$ & $30-34$ & 44 & 48 \\
\hline E. obsoletus & $34 \cdot 6$ & $42 \|$ & $29-33$ & 42 & 47 \\
\hline G. multicarinatus & 30 & $39 !$ & $28-32$ & 39 & 45 \\
\hline
\end{tabular}

* Mean body temperature, MBT (Licht, 1964b), at which the species regulates in a thermo-gradient and the incipient lethal temperature, CTM.

$\dagger$ Lowest temperature producing a reduction of $>20$ per cent in the subsequent reference tension at $24^{\circ} \mathrm{C}$.

† Cowles \& Bogert, 1944.

$\S$ Cole, 1943.

if Licht, 1964b.

The lowest temperature at which the muscle failed to respond to electrical stimuli at the end of the 5 min equilibration period was taken as the "lethal" temperature for the preparation. In most cases this loss of excitability was associated with a spontaneous contracture occurring within $30 \mathrm{sec}$ after the muscle was introduced into the heated Ringer's solution, and the muscle generally entered permanent rigor within $5 \mathrm{~min}$. Even in the absence of such contractures, no 
recovery of excitability was detected after subsequent cooling of the muscle. Longer exposures to lower temperatures (e.g. $15 \mathrm{~min}$ at $2^{\circ} \mathrm{C}$ lower) eventually resulted in a permanent loss of excitability, but contractures and the establishment of heat rigor did not occur at these lower temperatures.

\section{DISCUSSION}

Studies cited in the Introduction have demonstrated interspecific differences in the thermostability of saurian skeletal muscles. The present results clearly extend these findings in demonstrating comparable differences with respect to contractility in more normal physiological ranges of temperature. Furthermore, both the optimal temperatures and thermostabilities of the muscles correlate well with the extent of thermophily evident in the intact lizards (Table 1). To evaluate the physiological meaning of these adjustments in the excised muscles, it is convenient to consider the optima as being related to the preferred temperatures while viewing the thermostabilities of the muscles in terms of the heat tolerance of the species.

In addition to the present results, interspecific divergence has been demonstrated in the thermostabilities of sciatic nerves (Adensamer, 1934) and cardiac muscles (Dawson, 1960) from lizards. Experiments on skates, Raja, suggest that variations in the heat tolerance of species are reflected in differences in the thermostabilities of a wide array of tissues (Battle, 1926). Battle's results and those of Orr (1955) on the frog, Rana pipiens, further demonstrated considerable variations in the thermostabilities of different kinds of tissue from a single individual, the myoneural junctions being the most heat-sensitive tissue. As indicated in the present study (see Table 1), the somatic musculature tends to be more heat-resistant than the intact animal. This relationship is further verified in lizards by the fact that muscular contractions can be electrically induced in lizards previously paralyzed by exposures to incipient lethal temperatures (Licht, unpublished data). However, even though the muscles may not be the limiting factor for individual heat tolerance, some adjustment in the thermostability of this tissue would appear necessary to permit the diversity in tolerance limits evident among the five species studied. This follows from the fact that the lethal temperature of the muscle from Gerrhonotus is lower than that of the intact Dipsosaurus and Lma. It may be important that the value for the incipient lethal temperatures (CTM) of the five species corresponds closely to the lowest temperature at which their muscles were irreversibly damaged (Table 1).

Shifts in the optimal temperatures for contractility suggest that differences in thermal preferences of species are related to adjustments in the performance of individual skeletal muscles. Differences have also been demonstrated in the optimal temperatures for tension development by excised ventricles from these same species (Table 2). However, variations in the cardiac muscle tend to be greater than those observed in the skeletal muscle and they do not correlate as well with the thermal preferences of the respective species (cf. Sceloporus and Eumeces). It may well be that measurements of twitch tension do not adequately 
TABLE 2--OPTIMAL TEMPERATURES FOR VENTRICULAR TWITCH TENSION

\begin{tabular}{lccl}
\hline \multicolumn{1}{c}{ Species* } & \multicolumn{2}{c}{$\begin{array}{c}\text { Maximal ventricular } \\
\text { twitch tension }\end{array}$} & \multicolumn{1}{c}{ Reference } \\
\cline { 2 - 3 } & $\begin{array}{c}\text { Range } \\
\left({ }^{\circ} \mathrm{C}\right)\end{array}$ & $\begin{array}{c}\text { Midpoint } \\
\left({ }^{\circ} \mathrm{C}\right)\end{array}$ & \\
\hline D. dorsalis & $28-33$ & $30 \cdot 5$ & Dawson \& Bartholomew (1958) \\
S. occidentalis & $8-18$ & 13 & Dawson \& Poulson (1958) \\
E. obsoletus & $16-26$ & 21 & Dawson (1960) \\
G. multicarinatus & $2-8$ & 5 & Dawson, unpublished \\
\hline
\end{tabular}

* Arranged in order of decreasing thermophily. Preferred temperatures are similar to those for congeneric species in Table 1.

describe the physiological adjustments of the muscle or that such measurements are not comparable for different kinds of muscle. Analyses of a wide variety of tissue functions are clearly needed before the importance of thernal adjustments on this level of organization can be fully evaluated.

While the present results indicate that the muscles from various lizards are adjusted to different temperatures, it is important to consider whether these differences could be modified by altering environmental conditions. Hajdu (1951) found that the optimal temperature for tension development in skeletal muscle from summer frogs was several degrees higher than for winter frogs, and these shifts could be reproduced in the laboratory. Similar changes were reported for the temperature dependence of the retractor penis muscle from turtles kept at different temperatures in the laboratory (Brown, 1957). Seasonal changes in thermostability were recently reported in the skeletal muscles from several species of lizard (Ushakov, 1963), but these adjustments may be related to reproductive cycles rather than to temperature per se. However, the thermal tolerance of lizards can be increased by several degrees (Lowe \& Vance, 1955; Larson, 1961; Tremor, 1962), whereas the preferred temperatures are not readily modified by acclimation (Wilhoft \& Anderson, 1960). Therefore, even though the muscles may have the capacity to change with respect to thermostability, it does not follow a priori that comparable phenotypic adjustments in the optimal temperatures for tension development could be effected.

The close agreement between the interspecific differences in the temperature dependence of the whole muscles and those previously demonstrated in the muscle enzyme, myosin ATP-ase, from the same species (Licht, 1964a) suggests that these tissue differences are a result of very basic adjustments at the subcellular level.

Acknowledgements - I wish to thank Dr. William R. Dawson for his advice and guidance during the experimentation and preparation of this manuscript. I am also grateful to Dr. Dugald E. S. Brown for his many helpful suggestions during the course of this investigation. 


\section{REFERENCES}

Adensamer E. (1934) Über den Verlust der Leitfähigkeit des Nervus ischiadicus durch Erwärmung bei Lacertiliern. Z. Wiss. Biol. C. 21, 642-645.

BAtTLE H. I. (1926) Effects of extreme temperatures on muscle and nerve tissue in marine fishes. Trans. Roy. Soc. Can. 5, 127-143.

Brown D. E. S. (1957) Temperature-pressure relation in muscular contraction. In Influence of Temperature on Biological Systems (Edited by JoHnson F. H.), pp. 83-110. Amer. Physiol. Soc., Washington, D.C.

Cole L. C. (1943) Experiments on toleration of high temperature in lizards with reference to adaptive coloration. Ecology 24, 94-109.

Cowles R. B. \& BOGERT C. M. (1944) A preliminary study of the thermal requirements of desert reptiles. Bull. Amer. Mus. Nat. Hist. 83, 265-296.

Dawson W. R. (1960) Physiological responses to temperature in the lizard Eumeces obsoletus. Physiol. Zoöl. 33, 87-103.

Dawson W. R. \& Bartholomew G. A. (1958) Metabolic and cardiac responses to temperature in the lizard Dipsosaurus dorsalis. Physiol. Zoöl. 31, 100-111.

Dawson W. R. \& Poulson T. L. (1958) Effects of temperature on ventricular contraction in several lizards. Anat. Rec. (Abstr.) 131, 545.

HAJDU S. (1951) Observations on the temperature dependence of the tension developed by the frog muscle. Arch. Int. Physiol. 59, 58-61.

LARSON M. W. (1961) The critical thermal maximum of the lizard Sceloporus occidentalis occidentalis Baird and Girard. Herpetologica 17, 113-122.

Licht P. (1964a) The temperature dependence of myosin-adenosinetriphosphatase and alkaline phosphatase in lizards. Comp. Biochem. Physiol. 12, 331-340.

LIснт P. (1964b) The relation between thermoregulation and physiological adjustments to temperature in lizards. Ph.D. Thesis at the Univ. of Mich., Ann Arbor.

LowE C. H. Jr. \& VANCE V. J. (1955) Acclimation of the critical thermal maximum of the reptile Urosaurus ornatus. Science 122, 73-74.

OrR P. R. (1955) Heat death. II. Differential response of entire animal (Rana pipiens) and several organ systems. Physiol. Zoöl. 28, 294-302.

Patzl H. (1933) Vergleichende Untersuchungen über die Warmekontraktur und Warmelahmung der quergestreiften Muskeln von Eidechsen und Forschen. Pfiug. Arch. ges. Physiol. 231, 30-101.

Precht H. (1958) Concepts of the temperature adaptation of unchanging reaction systems of cold-blooded animals. In Physiological Adaptation (Edited by Prosser C. I.), pp. 50-77. Amer. Physiol. Soc., Washington, D.C.

Tremor J. W. (1962) The critical thermal maximum of the iguanid lizard Urosaurus ornatus. Dissert. Abstr. 23, 1462.

Ushakov B. P. (1959) Heat resistance of tissues as a specific character of poikilothermal animals. Zool. Zh. (in Russian with English summary) 38, 1292-1302.

Ushakov B. P. (1963) Changes in heat resistance of reptile muscle tissue in relation to season and reproductive cycle. Biol. Abstr. 44, 15246.

Ushakov B. P. \& Darevski I. S. (1960) Comparison of the heat tolerance of muscle fibers and behavior toward temperature in two sympatric species of semidesert lizards. AIBS transl. of Dokl. Akad. Nauk., SSSR 128, 770-773.

Wilhoft D. C. \& Anderson J. D. (1960) Effect of acclimation on the preferred body temperature of the lizard, Sceloporus occidentalis. Science 131, 610-611. 